\title{
ISOLATED MYOCARDITIS OF THE RIGHT VENTRICLE
}

\author{
BY \\ J. A. HAYES* \\ From the Mallory Institute of Pathology, Boston City Hospital, Boston, Mass.
}

Myocarditis is not uncommon at necropsy, one estimate placing the incidence at 3.5 per cent of all necropsies (Saphir, 1959). Usually the clinical picture in these cases has suggested some form of cardiomyopathy. This paper presents an instance where an unusual focal myocarditis of the right ventricle was revealed when the patient died, following a massive pulmonary embolism. The myocarditis was unusual in that it occurred only in the middle third of the lateral wall of the right ventricle: it was unusual also in its histological nature and no explanation for its presence was found.

\section{Case Report}

A 64-year-old white man, previously healthy, was admitted to the Boston City Hospital thirty minutes after having collapsed while talking to friends. He did not lose consciousness, his speech was slurred, and he had a left-sided paralysis. His personal and family background was normal.

On examination he was slightly obese but well-developed. He had slurred speech, a left-sided homonomous hemianopia, deafness, and facial anæsthesia. There was left-sided flaccid paralysis of arm and leg, and diminution of sensation over the entire left side. There was a left extensor plantar response, and the tendon reflexes on the right were exaggerated while those on the left were diminished.

The pulse rate was 64 a minute with sinus rhythm. The blood pressure was $180 / 80 \mathrm{~mm}$. The apex was $2 \mathrm{~cm}$. to the left of the mid-clavicular line in the fifth intercostal space. The heart sounds were normal with an early systolic murmur in the aortic area. The lungs were normal and there was no peripheral œdema. The electrocardiogram showed sinu-atrial bradycardia with sinus arrhythmia, notched $T$ waves, prominent $Q$ waves, and high voltage $Q R S$ complexes, which suggested left ventricular enlargement but no other definite lesion.

The white blood count was 10,000 per cu. mm. with a normal differential count. The E.S.R. was $26 \mathrm{~mm}$. (Wintrobe). Blood sugar, electrolytes, serum cholesterol, and liver function tests were normal. The cerebro-spinal fluid was normal at a pressure of $225 \mathrm{~mm}$. of water. The Lange curve was normal and the Wassermann negative.

This clinical picture was interpreted as being a focal right middle cerebral artery occlusion consequent on embolism from a mural thrombus overlying an early myocardial infarct.

Progress. Later electrocardiograms showed no change, so myocardial infarction was thought unlikely. Later the patient developed a fever of $102 \cdot 4^{\circ} \mathrm{F}$. associated with thrombophlebitis of the left long saphenous vein which was treated symptomatically. Ten days after admission while appearing to be recovering normal function in his paralysed left side, he was found dead in bed.

\section{Necropsy}

The body was that of a young looking man. The heart (weight 510 g.) showed generalized enlargement. The coronary arteries had minimal atheroma without occlusion or stenosis. The right atrium was thinwalled and dilated, its appendage being filled by laminated thrombus which was firmly adherent to normal underlying muscle. The right ventricle was dilated and its wall measured $3 \mathrm{~mm}$. in thickness. The lateral wall was studded with small, friable thrombi, firmly attached to the endocardium between the bases of the columnæ carnæ. The underlying muscle appeared normal. The left atrium was normal and the left ventricle hypertrophied $(17 \mathrm{~mm}$.) with some dilation. The valves were normal. There was an obliquely

* Now at the Department of Pathology, University of Bristol, Bristol, 8. 


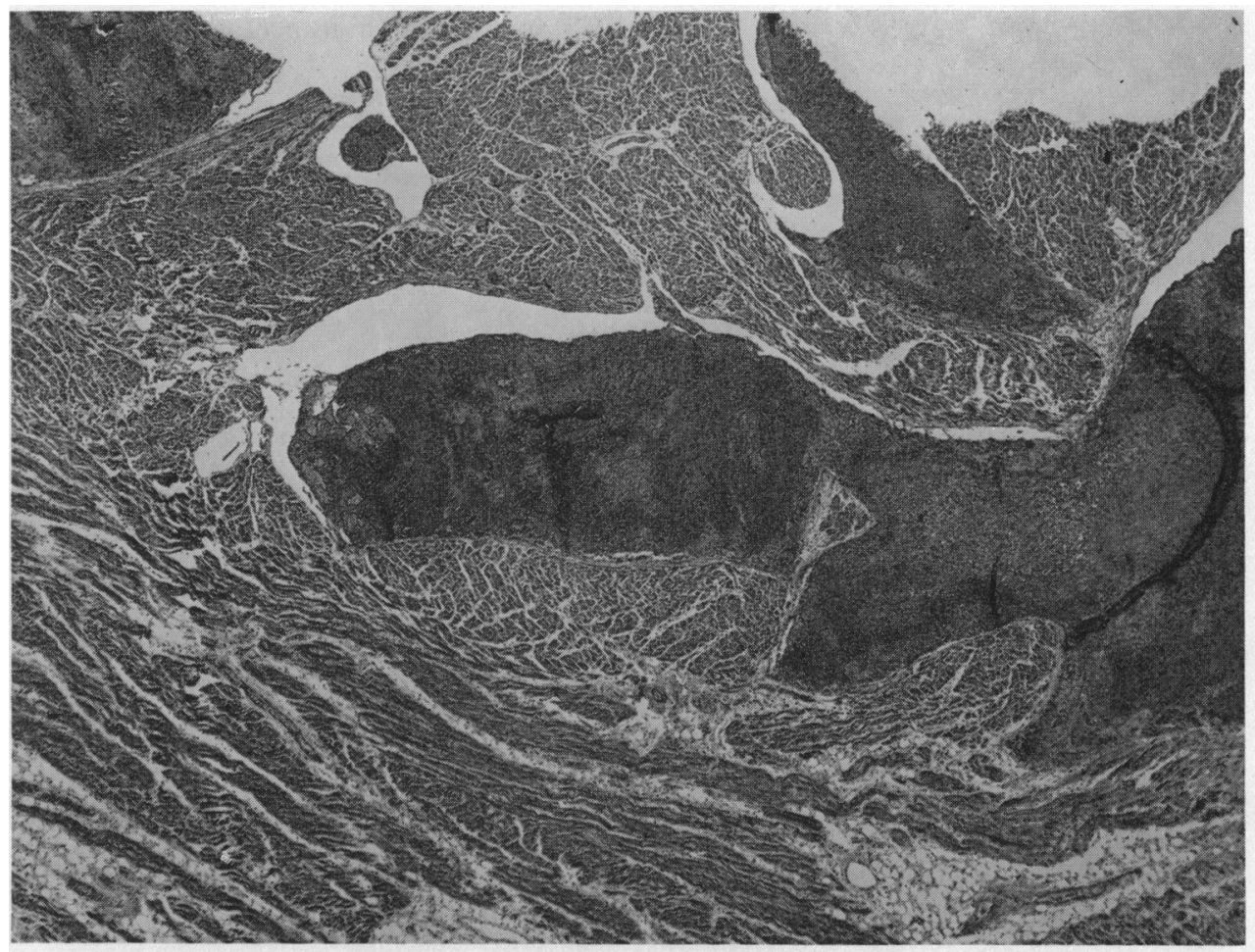

FIG. 1.-Wall of right ventricle, showing mural thrombi with some fatty infiltration of the myocardium. Hæmatoxylin and eosin: $\times 25$.

placed foramen ovale in the intra-atrial septum of $7.5 \mathrm{~mm}$. diameter, which was incompletely occluded by the overlapping walls.

The lungs (weight 810 g.) were congested and œdematous with a recent peripheral infarction in the right upper lobe. The pulmonary arterial trunk was completely occluded by a large coiled up embolus which had the pattern of a leg vein cast.

The brain (weight $1550 \mathrm{~g}$.) showed a recent infarction in the periphery of the right parietal lobe. The spleen, kidneys, and liver showed passive congestion. There was a cortical adenoma of the right adrenal.

Histological Examination. The middle third of the myocardium of the lateral wall of the right ventricle showed focal collections of lymphocytes and histiocytes with an occasional plasma cell and neutrophil polymorph (Fig. 1). The cells were arranged about groups of four to six muscle fibres which showed vacuolar degeneration, hyaline granularity, loss of cross-striations, and frequent rupture. The affected fibres had large polygonal nuclei, often appearing like the "smudge cells" in lymphatic leukæmia. Intervening fibres were normal and the endocardial and epicardial fibres were unaffected. Some of the ruptured fibres showed histiocytes and lymphocytes within the sheath (Fig. 2). No giant cells were seen. In the most severely affected areas, there was a deposition of fibrin with early collagen formation and fibroblast proliferation. Sections from the other heart chambers showed no abnormality apart from an acute inflammatory reaction in the muscle underlying the right appendicular thrombus.

\section{Comment}

It is suggested that paradoxical embolism to the brain occurred through the patent foramen ovale, the origin of the embolus being in the right atrium. No reason can be given for the presence of the thrombus at this site. The resulting immobilization resulted in leg vein thrombosis which caused a massive pulmonary embolism when the patient was ambulant. 


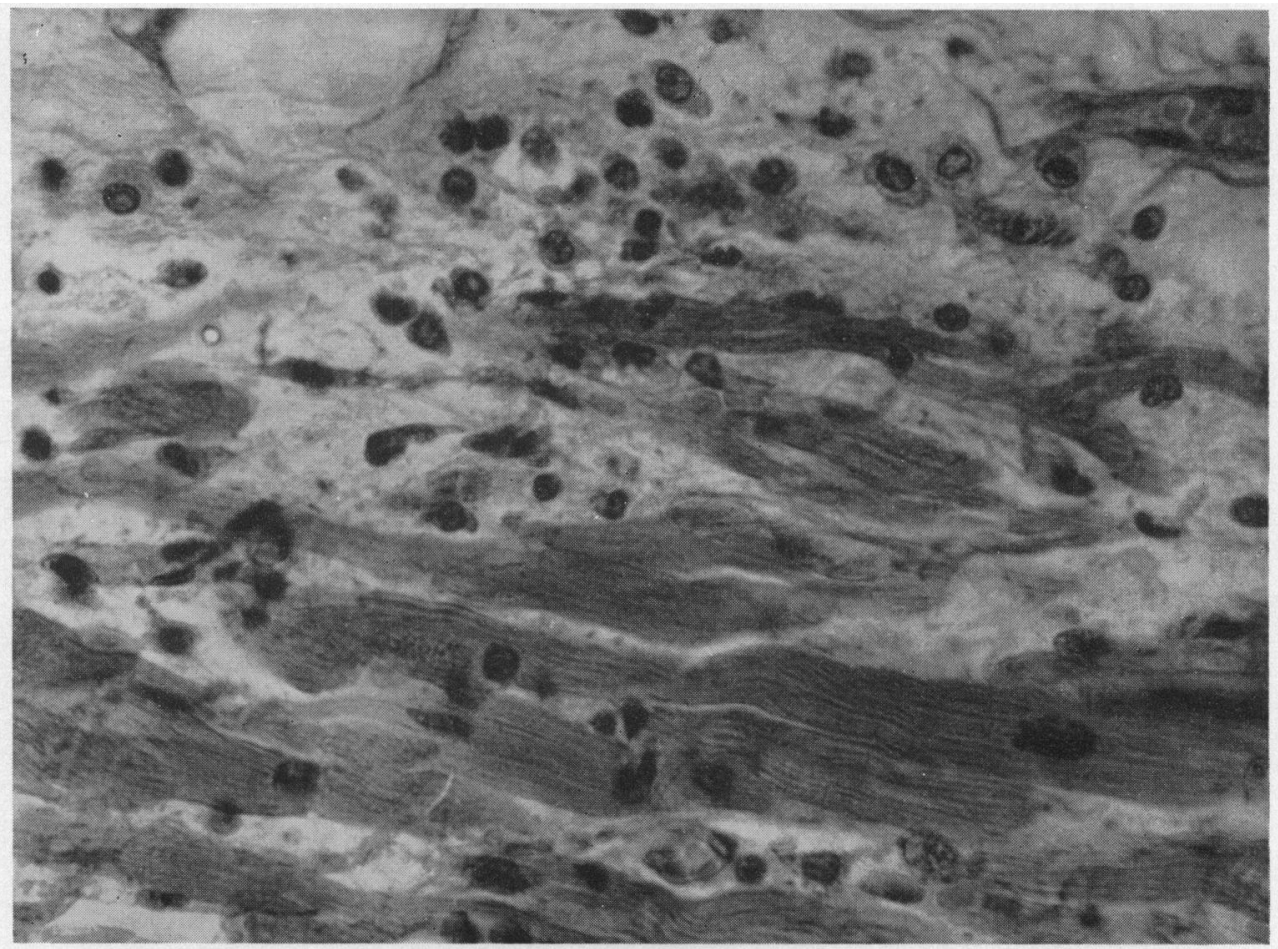

FIG. 2.-Myocardium showing fragmentation of muscle fibres with intra- and inter-fibrillary œdema. Infiltration by lymphocytes, histiocytes, and an occasional plasma cell. Histiocytes can be seen within the fibres in the upper part of the field. Hæmatoxylin and eosin: $\times 330$.

It is remarkable that the patient felt well and presented no clinical signs in the presence of the extensive myocardial lesion in the right ventricle. This lesion was not due to vascular insufficiency, even of the "focal myocytolytic" type (Schlesinger and Renier, 1955). A similar picture may be produced by viral infection (Gould, 1953), beri-beri (Toreson, 1944; and Weiss, 1940), drug hypersensitivity (Lynch and Wyatt, 1957), adult toxoplasmosis (Pinkerton and Henderson, 1941), trypanosomiasis (Koppisch, 1957), disseminated coccidioidomycosis (Rheingold, 1950), trichnia spiralis infestation (Weller and Shaw, 1932), uræmia and glomerulo-nephritis (Gouley, 1940; and Gore and Saphir, 1948), or Kwashiorkor (Trowell et al., 1954), but these are excluded by the clinical history in this patient.

Isolated or Fiedler's myocarditis is frequently found in seemingly healthy patients who die quite suddenly (Englehardt and Bruno, 1943; and Marcuse, 1947). These patients do not usually show muscle fibre degeneration, and when this is present the degeneration is regarded as being secondary to the interstitial œdema. Also no endocardial or epicardial changes occur, although mural thrombi have been reported (von Bonsdorff, 1939). The present patient showed œdema which was prominent only at the sites of fibre rupture and was, therefore, thought to be secondary to the focal fibrillary necrosis.

There is no apparent connection with endomyocardial fibrosis but a suggestion has been made that in these cases the fibrosis is preceded by a sensitivity reaction that produces œdema fluid rich in acid mucopolysaccharide (Becker et al., 1953). No acid mucopolysaccharide was identified in this case using the periodic acid-Schiff technique. The presence of the mural thrombi presents a problem as they were not coincident with the underlying myocarditis. Neither did the adjacent endocardium show an inflammatory reaction. 


\section{Summary}

An unusual type of myocarditis is described which showed focal involvement of the middle third of the lateral wall of the right ventricle. The myocardial changes were characterized by rupture of muscle fibres, round-cell infiltration, and interstitial œdema. There were multiple small mural thrombi not associated with the underlying myocarditis.

No explanation has been found for the presence of these phenomena. One particular point of interest was the absence of symptoms and clinical signs.

My thanks are due to Dr. D. Campagna-Pinto, Prof. J. N. P. Davies, and Dr. G. K. Mallory for their help.

\section{References}

Becker, B. J. P., Chatgidkis, L. B., and van Linjen, B. (1953). Circulation, 7, 345.

Engelhardt, H. T., and Bruno, F. B. (1943). New Eng. med. J., 228, 222.

Gore, I., and Saphir, O. (1948). Amer. Heart J., 36, 390.

Gould, S. E. (1953). Pathology of the Heart. Chas. Thomas, Springfield, Ill.

Gouley, B. A. (1940). Amer. J. med. Sci., 200, 39.

Koppisch, E. (1957), in W. A. D. Anderson, Pathology. C. V. Morsby, St. Louis, Mo.

Lynch, J. B., and Wyatt, J. (1957). Brit. Heart J., 19, 173.

Marcuse, P. M. (1947). Arch. Path., 43, 602.

Pinkerton, H., and Henderson, R. G. (1941). J. Amer. med. Ass., 116, 807.

Rheingold, I. M. (1950). Amer. J. clin. Path., 20, 1044.

Saphir, O. (1959). Amer. Heart J., 57, 639.

Schlesinger, M. J., and Reiner, L. (1955). Amer. J. Path., 31, 443.

Torenson, W. E. (1944). Arch. intern. Med., 73, 375.

Trowell, H. C., Davies, J. N. P., and Dean, R. F. A. (1954). Kwashiorkor. Ed. Arnold, London.

von Bonsdorff (1939). Acta. med. Scand., 100, 403.

Weiss, S. (1940). J. Amer. med. Ass., 115, 832.

Weller, C. V., and Shaw, M. (1932). Trans. Ass. Amer. Physicians, 47, 41. 